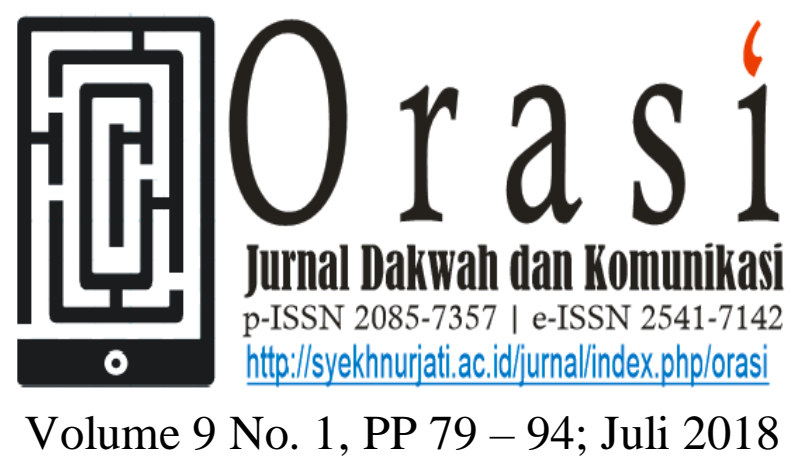

\title{
FASHION, KARISMA DAN SUARA ULAMA: MEMBACA GAYA DAKWAH KIAI SHALIH DARAT
}

\author{
Aflahal Misbah(*) \\ Mahasiswa Pascasarjana Interdisciplinary Islamic Studies/Islam Nusantara \\ UIN Sunan Kalijaga Yogyakarta \\ aflahalmisbah@gmail.com ${ }^{(*)}$
}

\begin{abstract}
ABSTRAK
Kiai Shalih Darat merupakan tokoh pembaru dakwah Islam di Nusantara Akhir Abad 19. Tulisan ini berusaha mengkaji lebih dalam gaya dakwahnya berbasis pada tiga poin gagasannya tentang mekanisme dakwah, yakni; fashion, karisma dan suara ulama. Tiga poin ini di ulas lebih dalam kemudian dicari relasi dan makna secara integral dari ketiganya. Hasilnya, dalam berdakwah, Kiai Shalih berusaha memopulerkan Islam melalui simbol fashion sebagai medianya. Fashion merupakan wujud ekspresi kesuksesan atau kekayaan seorang ulama yang mencerminkan independensi ulama dalam kehidupan profan. Dari sini, Fashion kemudian dijadikannya sebagai simbol pembeda, role model sekaligus ekspresi kritik. Fashion, menurutnya, menjadi basis dari munculnya karisma seorang ulama dalam ruang sosial yang penuh dengan persoalan kompleks di dalamnya, terutama ekonomi. Selanjutnya, karisma memiliki andil besar terhadap keefektifan fatwa atau suara ulama yang diproduksi dan disebarkan di masyarakat. Dari tiga poin ini, dapat dipahami bahwa gaya dakwah Kiai Shalih tidak hanya menekankan pada strategi atau cara dalam mentransmisikan keilmuan Islam, proses intensifikasi keakraban dalam relasi pemimpin dengan masyarakat menjadi ciri khasnya dalam berdakwah. Proses ini dicapainya melalui pengadaan sikap responsif terhadap struktur nalar dan kebutuhan masyarakat. Gaya dakwahnya bisa dikatakan sebagai upaya menampilkan wajah Islam yang responsif terhadap keadaan sosial di sekitarnya.
\end{abstract}

Kata Kunci: Kiai Shalih, Dakwah, Fashion, Kharisma, dan Suara Ulama. 


\section{PENDAHULUAN}

Jika melihat proses islamisasi di Indonesia saat ini, mungkin akan timbul opini sebagai peristiwa tautologis ketika mengkaji kembali sejarah gerakan revivalisme Islam di Indonesia yang berakar sejak abad 19, meski Ricklefs (2001: 169) beranggapan hal ini masih sedikit diketahui. Asumsi demikian cukup beralasan mengingat kehadiran Islam sempat terisolir beberapa saat pada masa Orde Baru. Pasca Orde Baru, proses Islamisasi kembali menemukan momentumnya ditandai dengan dua wajah yang cukup menonjol, yaitu; wajah skriptural dan wajah substansial (Jati, 2015: 142). Memang, proses Islamisasi yang berlangsung sekarang tidak bisa disamakan dengan peristiwa yang terjadi pada masa lampau, karena iklim sosial yang berbeda. Namun, terdapat pola yang mirip seperti menghadirkan Islam di ruang publik melalui simbol-simbol yang diasosiasikan dengan Islam.

Artikel ini berusaha membaca kembali pergerakan dakwah di masa silam sebagai basis untuk memahami perkembangan, perubahan, serta pergeseran pola-pola islamisasi yang terjadi di Indonesia, terutama terkait penghadiran simbol-simbol Islam di ruang publik melalui produk budaya, seperti fashion. Ekspresi beragama banyak ditampilkan melalui islamisasi simbol sebagai strategi menarik perhatian dan pengakuan khalayak. Baik dulu dan sekarang, keduanya memiliki pola yang hampir sama di mana simbol produk budaya dibalut dengan Islam dimunculkan ke permukaan oleh para pendakwah. Berangkat dari tema ini, penulis tertarik untuk memahami lebih dalam proses dakwah yang berlangsung di Indonesia dari masa ke masa. Karenanya, dalam tulisan ini penulis lebih fokus pada pergerakan dakwah di masa silam, terutama Akhir Abad 19 sebagai akar dari munculnya revivalisme Islam.

Proses pembacaan ini merupakan pengembangan dari makalah penulis sebelumnya, "Fashion" dalam konstruksi otoritas ulama" (Misbah, 2017). Dalam tulisan ini, titik penekanan lebih pada membaca gaya dakwah Kiai Shalih berbasis pada tiga poin pandangannya tentang mekanisme dakwah, yaitu; fashion, karisma, dan suara ulama. Pemusatan terhadap gerakan dakwahnya merujuk pada status dan perannya sebagai tokoh reformis realis yang mengislamkan masyarakat, Jawa khususnya (Basri, 2008). Dia berhasil menyebarkan dan membumikan ajaran Islam ortodoks melalui penerbitan karya-karyanya beraksara Pegon, meski secara historis kehadiran Islam ortodoks sudah muncul sejak abad 16 (Umam, 2011: 264). Di sisi lain, Kiai Shalih juga salah satu aktor 
kunci yang mampu mendialogkan Makkah dengan Pesantren dan Pesantren dengan masyarakat (Burhanudin, 2007: 123-130). Konsolidasi yang dilakukannya berimplikasi besar terhadap perkembangan Islam di Indonesia, terutama dalam tradisi pesantren. Berpijak pada argumen tersebut, kajian terhadap gerakan dakwahnya merupakan bagian penting untuk memahami genealogi dakwah Islam di Indonesia.

Sebelum memulai diskusi ini, penulis mempunyai beberapa pertanyaan yang menjadi fokus dalam tulisan ini; Pertama, bagaimana status dan makna fashion sebagai salah satu komponen penting dalam mekanisme dakwah? Kedua, bagaimana fashion, karisma, dan suara ulama mampu berhubung erat satu sama lain dalam mekanisme dakwah? Ketiga, dari ketiga komponen itu, bagaimanakah gaya dakwah Kiai Shalih? Pertanyaan terakhir sifatnya lebih reflektif, penulis berusaha memahami gaya dakwah Kiai Shalih melalui ketiga komponen tersebut. Meski tidak mampu menggambarkan secara utuh, hasil dari tulisan ini dapat dijadikan sebagai langkah awal untuk memahami gaya dakwah Kiai Shalih secara komprehensif, lebih luasnya pergerakan dakwah Akhir Abad 19.

\section{BIOGRAFI DAN PEMIKIRAN KIAI SHALIH}

Kiai Shalih Darat atau Muhammad Shalih as-Samarani lahir di Jepara 1820 $\mathrm{M} / 1235 \mathrm{H}$, tepatnya sebelum perang Diponegoro (1825-1830) dimulai. Ayahnya, Kiai Umar, merupakan ulama sekaligus pejuang dalam perang Diponegoro. Shalih kecil tumbuh di lingkungan santri dan para pejuang perang Jawa. Dia belajar agama pertama kali langsung kepada ayahnya seperti ilmu nahwu, shorof, akidah, akhlak, hadis dan fiqih, kemudian pindah dari satu ulama ke ulama lain, dari satu pesantren ke pesantren lain sebelum akhirnya dibawa oleh ayahnya ke Makkah (Dzahir, 2012: 56). Selama pengembaraan ini, dia belajar kepada beberapa ulama kenamaan di Jawa dengan kitab-kitab yang berbobot. Gurunya antara lain; Kiai Muḥammad Syahīd (Pati), Kiai Raden Haji Muḥammad Ṣālị̣ ibn Asnāwī (Kudus), Kiai Isḥaq (Semarang), Kiai Abu 'Abdillah Muhammad al-Hādi ibn Bā'uni (Semarang), Kiai Darda' (Semarang) (asSamārānī, 1318 H: 118-119).

Pada tahun \pm 1835 M Kiai Shalih di ajak ke Makkah oleh ayahnya dan singgah beberapa saat di Singapura (Munir, 2008: 44). Selama di Makkah, Kiai Shalih belajar kepada beberapa ulama prominen seperti: Syaikh Muḥammad al-Muqrī al-Mișrī alMakkī, Syaikh Muḥammad ibn Sulaimān 
Hasbullah, Syaikh Ahmad ibn Zaini Dahlān, Syaikh Aḥmad an-Nahrawī alMisrī al-Makkī, Sayyid Muhammad Șāliḥ az-Zawāwī al-Makkī, Kiai Zāhid atau Zaid, Syaikh 'Umar asy-Syāmi, Syaikh Yūsuf as-Sūnbulawi al-Misrī, Syaikh Jamal, mufti Hanafi di Makkah (asSamārān̄i, 1318 H: 119-120). Bermacammacam kitab berbobot menjadi konsumsinya setiap hari selama di Makkah sehingga karakter dan kedalaman ilmunya tidak diragukan lagi. Beberapa guru seperti Syaikh Muḥammad ibn Sulaimān Hasbullah, Syekh Ahmad Ibn Zaini Dahlan, dan Kiai Zahid- memberinya ijazah sebagai pertanda berhak dan layak untuk mengajarkan dan menyebarkan ilmunya.

Dakwah Kiai Shalih sudah dimulai saat dia masih menuntut ilmu di Makkah. Kiai Shalih sempat mengajar di Makkah sebelum akhirnya diculik oleh Kiai Hadi Girikusumo (Dzahir, 2012: 11-12). Kiai Hadi dianggap sebagai orang yang paling berjasa membawa Kiai Shalih pulang ke tanah air. Namun, Munir (2008: 44) menyebut bahwa kepulangan Kiai Shalih disebabkan oleh wafatnya ayahnya. Kiai Shalih kembali ke Nusantara pada tahun \pm 1870 M, merujuk pada status Syekh Mahfudz at-Tirmisi sebagai murid Kiai Shalih pada \pm 1870 M (Mas'ud, 2004: 138), karya tulisnya terjemah al-Hikam dan Pesantren Darat yang didirikan
(Dzahir, 2012: 16-17) serta studi Kiai Shalih kepada Syaikh bin Ahmad Bafaqih saat di Semarang 1870/1871 M (Steenbrink, 1984: 131-132).

Pasca kembali dari Makkah, Kiai Shalih aktif melakukan kegiatan dakwahnya mulai dari mengabdi atau membantu mengajar di Pesantren Salatiyang, Purworejo, hingga akhirnya mendirikan Pesantren Darat yang semula adalah langgar peninggalan mertuanya, Kiai Murtadho (Dzahir, 2012: 15-17). Dari Pesantrennya ini, beberapa murid Kiai Shalih menjadi pemimpin kenamaan Awal Abad 20, seperti Syekh Makhfudz atTirmisi ahli Hadits dikenal luas dunia internasional, Syekh Hasyim Asy'arie pendiri Nahdhatul Ulama, Syekh Ahmad Dahlan pendiri Muhammadiyah, serta beberapa Kiai besar lain yang menjadi aktor penting di daerahnya masing-masing.

Selain di Pesantren, Kiai Shalih aktif melakukan kegiatan dakwah di berbagai daerah seperti di Pendopo Kabupaten Demak, di Kabupaten Bulus Purworejo, serta di beberapa daerah lain (Munir, 2008: 58). Dalam kegiatan dakwahnya ini, terdapat cerita menarik ketika Kiai Shalih berdakwah di Pendopo Demak. Saat itu, sedang berlangsung acara rutin pengajian bulanan yang kebetulan dihadiri oleh R.A Kartini, Pahlawan Kemerdekaan Nasional yang ditetapkan oleh Soekarno melalui Keputusan Presiden Republik Indonesia 
No.108 Tahun 1964. Dalam pengajian itu, Kartini tertarik mendengar penjelasan tafsir al-Fatihah dari Kiai Shalih. Ketertarikan ini kemudian menyebabkan Kartini mendesak pamannya untuk menemaninya menemui Kiai Shalih. Dari sinilah, kemudian muncul pendapat bahwa tafsir Faid ar-Rahman, sebuah tafsir alQuran berbahasa Jawa, karya Kiai Shalih sengaja dibuat untuk Kartini (Masrur, 2012: 37-43).

Sepanjang hidupnya, Kiai Shalih hanya mengabdi untuk ilmu dan umat. Perjuangan Kiai Shalih secara fisik harus terhenti setelah menghembuskan nafas terakhirnya pada hari Jum'at Legi tanggal 28 Ramadhan $1321 \mathrm{H}$ atau 18 Desember 1903 M. Dia dimakamkan di Pemakaman Umum Bergota Semarang (Munir, 2008: 33). Kendati demikian, pemikirannya tidak berhenti mengalir dari sepeninggalnya hingga sekarang.

\section{ULAMA DAN FASHION:}

\section{ISLAMISASI SIMBOL}

Sejauh kemampuan analisa penulis, gerakan dakwah Kiai Shalih dapat dipetakan dalam tiga domain; a) menggalang dukungan masyarakat untuk melawan kolonial melalui gerakan bawah tanah, b) mengonsolidasi jaringan intelektual ulama, dan c) islamisasi masyarakat melalui dua cara, yaitu; secara fisik dengan menjadikan tradisi ulama sebagai standar berperilaku, bersikap, maupun berpenampilan, dan secara keilmuan dengan cara berdakwah melalui pesantren, pengajian umum maupun karya tulis.

Pemetaan di atas bersandar pada argumen bahwa tidak adanya dukungan politik yang kuat dalam skala nasional maupun internasional. Elit kerajaan dan birokrasi Jawa saat itu begitu terikat dengan pemerintah kolonial. Kalangan elit kerajaan sudah tergeser dari urusan-urusan politik dan mengalihkan perhatian mereka ke bidang budaya (Ricklefs, 2001: 163, 168). Dalam skala internasional, pada tahun 1883, Kiai Shalih sudah berupaya untuk membujuk Turki Ottoman untuk menghilangkan dominasi kolonial di Jawa (Bruinessen, 1998: 39). Namun, tampaknya tak ada tanggapan serius dari kerajaan Turki.

Dalam bagian ini, pembahasan lebih difokuskan pada islamisasi yang dilakukan Kiai Shalih melalui simbol budaya, terutama fashion. Simbol atau lambang merupakan sarana atau mediasi untuk membuat dan menyampaikan suatu pesan, menyusun sistem epistemologi dan keyakinan yang dianut (Soekanto, 2001: 187). Demikian halnya fashion sebagai salah satu simbol budaya, yang memiliki makna cukup kompleks di dalamnya. Dalam pandangan Barnard (2011: 2) fashion memiliki makna pada setiap 
pembawaannya. Ekspresi setiap pembawa tentu berbeda satu dengan yang lainnya, sehingga nampak dari keragaman fashion yang tidak terbatas jumlahnya. Unsurunsur budaya, ekonomi, pendidikan, pemikiran bahkan negara yang terkait dengan latar belakang si pemakai ikut berpengaruh dalam membentuk cara berpakaian bagaimana yang tepat. Karenanya, cukup beralasan mengapa Kiai Shalih sangat menekankan pentingnya fashion di kalangan ulama.

Kaitannya dengan ulama, fashion tentunya tidak lagi sebatas simbol budaya yang mencerminkan identitas atau kepribadian seorang ulama, melainkan juga agama tercakup di dalamnya. Penilaian orang tentang pakaian yang dikenakan seorang ulama tentu berbeda ketika menilai pakaian yang dikenakan oleh orang biasa atau kaum bangsawan. Pakaian yang dipakai ulama bisa jadi ditetapkan oleh yang melihat sebagai standar berpakaian yang dianjurkan dalam Islam. Konsekuensinya, meniru gaya berpakaian ulama akan dianggap sebagai bagian dari tuntunan ajaran Islam. Kiai Shalih dalam hal ini tidak memberikan acuan standar pasti mengenai gaya berpakaian seorang ulama yang dimaksudnya. Dia justru mengutip pandangan Imam Hanafi yang memiliki konteks sosial dan budaya yang berbeda (as-Samārān̄̄, 1317: 82). Tentu hal ini menjadi cukup aneh melihat betapa banyaknya pernyataan tautologis yang ditulisnya (as-Samārān̄̄, 1317: 81-83). Hal ini menunjukkan betapa pentingnya fashion bagi ulama, namun fashion seperti apa yang tepat dan sesuai dengan kondisi sosial dan kultur di negaranya justru tidak dirumuskan.

Meski demikian, dari beberapa pernyataannya yang sering menulis kata gombal (pakaian kusut atau sobek-sobek), ino (hina atau rendah), dan ngere (menampilkan diri sebagai orang miskin) bisa diambil suatu konsep umum bahwa pakaian yang dimaksud adalah bersih, rapi dan mewah (as-Samārān̄̄, 1317: 81, 83). Yang jelas, Kiai Shalih tidak menjadikan standar pakaian pemerintah kolonial sebagai pakaian yang patut dipakai oleh ulama, seperti dasi, topi atau jas (asSamārānī, 1374: 25).

Upaya Kiai Shalih menempatkan fashion sebagai salah satu bagian penting dalam diri ulama nampaknya menjadi bagian dari cara Kiai Shalih untuk memopulerkan Islam. Fashion yang dianggapnya sebagai salah satu ekspresi kekayaan seorang ulama (as-Samārān̄ī, 1317: 81, 83) adalah sesuatu yang penting untuk ditampilkan di masyarakat yang sedang dilanda kemiskinan. Menurutnya, kondisi tersebut telah mengubah pandangan masyarakat bahwa yang disebut orang mulia adalah orang kaya (as- 
Samārānī, 1317: 82). Hal ini merupakan kesempatan bagi ulama untuk masuk di dalamnya. Hadirnya ulama dengan fashion yang rapi, bersih, dan mewah akan berimplikasi pada rasa simpatik masyarakat terhadap ulama, sehingga akan timbul pola imitasi yang dilakukan oleh pengikutnya. Dari sini, Islam mulai tumbuh di masyarakat.

Meski hanya sebatas simbol dan hanya di permukaan, Kiai Shalih tidak menganggap hal ini sebagai persoalan serius. Asumsi ini didasarkan pada pandangannya yang lebih mengutamakan syiar Islam daripada harus menyelidiki tingkat kedalaman pengetahuan atau ketulusan seseorang dalam menjalankan aturan Islam (as-Samārānī, 1317: 161). Masing-masing orang memiliki tingkat pemahaman, pengamalan dan gayanya sendiri dalam mempraktekkan, sehingga tidak bisa dipaksakan harus seideal seperti yang dibayangkannya.

\section{FUNGSI SIMBOL FASHION}

Simbol menjadi hal penting dalam mendakwahkan Islam sebagaimana terlihat dari penjelasan sebelumnya. Perhatian dari Kiai Shalih bukan hanya terletak pada diseminasi gagasan keilmuan Islam melainkan juga pendistribusian simbolsimbol yang dikaitkan dengan Islam. Penekanan pada fashion, secara implisit telah menunjukkan adanya pengaitan antara agama dan simbol sebagai dua dimensi yang harus berjalan secara simultan dalam mendakwahkan Islam, meski Kiai Shalih tidak menolak ketika salah satu dari keduanya lebih unggul dalam prakteknya.

Fashion sebagai simbol budaya memiliki kaitan erat dengan kondisi lingkungan yang melingkupinya. Status dan makna fashion seseorang tidak bisa disamakan satu dengan yang lain, apalagi dalam ruang dan waktu yang berbeda. Lalu bagaimana ketika fashion dihubungkan dengan ulama sebagai pemimpin agama? Bagaimana kedudukan dan maknanya dalam struktur nalar Kiai Shalih? Bagian ini berusaha menjawab pertanyaan itu beserta lanskap sosial yang menyertainya. Bagaimanapun, Kiai Shalih berada dalam ruang yang penuh dinamika dan perubahan sosial di dalamnya, karenanya tidak mungkin mengabaikan hal itu.

Poin pertama yang bisa dipahami dari status fashion adalah ketika Kiai Shalih berusaha menempatkan ulama sebagai orang berbeda dari individu atau kelompok di lingkungannya. Kiai Shalih berkata;

"Anapun ingdalem iki zaman akhir turut patbelas utowo telulas moko sayukjane kedue wongkang ahli ilmu utowo poro ulama utowo poro shufi moko arep ngetohiraken ni'matullah kelawan bagusaken penganggone ojo gombal kerono penganggo gombal iku ngucap a'thuni aku 
jaluk-jaluk lan arep bagusaken panganane lan penganggone kerono targhibun lil-mu'minin ojo kasi wong ahli ilmu iku podo ketingalan gombal lan ino lan ngere mengkono ojo". (as-Samārān̄i, 1317: 81)

Artinya: Adapun pada Abad $14 \mathrm{H}$, orang yang berilmu, ulama, atau para sufi hendaknya menampakkan nikmat [yang diberikan] Allah dengan cara memperindah pakaiannya, jangan [memakai pakaian] gombal [kusut atau sobeksobek] karena pakaian itu [sebenarnya] memiliki makna a'thuni aku minta-minta. Hendaknya makan yang enak-enak dan memperindah pakaiannya untuk targhibun lil mukminin jangan sampai orang berilmu itu tampak [memakai pakaian] gombal, hina [jelek], atau ngere [tampil seperti orang miskin], demikian jangan.

Kutipan di atas memang menunjukkan status fashion sebagai media diferensiasi ulama dengan yang lain. Namun, untuk menetapkan secara spesifik 'berbeda dengan siapa', ini membutuhkan pendapatnya yang lain untuk memahami konstruksinya mengenai diferensiasi ulama. Sebelum beranjak ke poin ini, ada petunjuk lain terkait makna fashion yang patut diperhatikan dalam kutipan tersebut. Fashion di situ tidak lagi sebatas produk budaya yang berfungsi menutupi tubuh atau hiasan, fashion sudah bermakna sebagai ekspresi atau simbol kekayaan seorang ulama. Menurutnya, kekayaan ulama merupakan nikmat Allah yang harus diekspresikan salah satunya melalui fashion. Asumsi ini kemudian dipertegas lagi bahwa "Moko dadi mukmin zaman akhir utomo sugihe supoyo ojo katon ino gombal mungguh peningale wong bodobodo" (as-Samārānī, 1317: 83) (Artinya: maka menjadi orang beriman pada zaman akhir itu sebaiknya kaya supaya tidak terlihat hina dan (penampilan) kusut menurut orang bodoh).

Ulama, menurutnya, harus menjadi orang kaya agar tidak terlihat rendah dalam kacamata orang bodoh. Orang bodoh di situ jelas merujuk pada masyarakat awam yang saat itu tereksploitasi secara besar-besaran oleh kolonial. Kemiskinan dan kebodohan menjadi gambaran umum masyarakat saat itu akibat intervensi kolonial terhadap urusan pribumi yang berlebihan (Baca Ricklefs, 2001: 158-162; Suminto, 1985: 28; Munir, 2007: 13-14). Karenanya, Kiai Shalih berusaha membangun kembali peradaban masyarakat saat itu melalui doktrin-doktrin yang disematkan dalam simbol budaya. Melalui ulama, cara ini mungkin dianggap lebih efektif karena ulama (kiai) menjadi rujukan masyarakat secara umum.

Sampai di sini, kedudukan fashion jelas menjadi identitas pembeda dengan masyarakat awam. Kendatipun secara bersamaan fashion juga dijadikan sebagai simbol bahwa ulama merupakan role model, panutan, rujukan, dan sumber bagi 
spirit beragama umat tanpa harus menanggalkan aktivitas profan. Tampilnya ulama sebagai orang yang mapan tentu sangat relevan bagi umat di tengah kondisi pesimistis akibat kebijakan kolonial. 'Fashion ulama' secara tidak langsung menjadi legitimasi otoritatif dan spirit umat untuk terus membangun kondisi perekonomiannya yang sedang terpuruk.

Kekayaan dengan kata lain juga menunjukkan status ulama yang independen dari ketergantungan terhadap orang lain. Kiai Shalih mengatakan "lan maleh supoyo ojo ono wongkang ahli ilmu utowo poro mukmin iku depe-depe mareng wong ahli dunyo" (as-Samārān̄̄, 1317: 83) (Artinya: dan juga supaya tidak ada orang berilmu menggantungkan diri pada ahli dunia). Dengan kata lain, ulama harus mandiri dalam segala bidang, baik agama maupun ekonomi. Jika mencermati pernyataan ini secara lebih dalam, Kiai Shalih bukan hanya membuat diferensiasi ulama dengan masyarakat awam melalui fashion, melainkan juga antar ulama lain yang perilakunya tidak sesuai dengan pemikirannya. Pada masa itu, terdapat ulama yang menggantungkan hidupnya dengan orang lain. Kiai Shalih berkata, "Koyo galibe juhlah at-țalabah, podo moco hadis mi'rāj sejane amreh jah lan amreh bondo dunyo mider-mider ono ing deso-deso utowo kampung-kampung kelawan mampir wong barang utowo mampir dalang wayang” (as-Samārān̄̄, 1317: 282) (Artinya; Seperti lazimnya pelajar yang bodoh saat ini, membaca [atau berpijak pada] Hadis Mi'rāj sejatinya hanya untuk memperoleh pujian dan harta benda, berkunjung ke desa-desa atau ke kampung-kampung dengan singgah sebentar atau menjadi dalang wayang).

Adanya ulama keliling juga dikonfirmasi kebenarannya oleh Steenbrink (1984: 154) bahwa ada beberapa ulama keliling dari rumah ke rumah, baik itu dari orang Arab atau Indonesia yang mencari calon jamaah haji untuk mereka sendiri atau untuk syekh haji tertentu, di samping juga memberikan ceramah agama, menjual jimat, air zamzam dan tasbih. Selain dengan ulama keliling, Kiai Shalih juga berupaya membedakan ulama dalam komunitas santri dengan ulama di bawah lingkaran kolonial. "Koyo galibe iki zaman, galibe tạlib al-ilmi yen wus oleh ilmu kedik moko enggal-enggal ginawe khidmah a $\dot{z}$-żulmah utowo enggal-enggal ngaku dadi guru ing hale durung ngerti kalām al-'Arab, ora ono sejane amung amreh bondo dunyawiyah koyo amreh sawah sangking ratu utowo supoyo kanggo magang ratu, na'üżu bi Allah min 'ilmi lā yanfa'u." (asSamārān̄̄, 1317: 274) (Artinya: Seperti umumnya saat ini, lazimnya seorang penuntut ilmu jika sudah memperoleh ilmu sedikit, maka segera digunakan untuk 
melakukan perbuatan zalim, atau segera digunakan untuk mengaku sebagai guru padahal belum memahami bahasa Arab, tidak ada tujuan lain kecuali untuk mencari harta benda seperti mencari sawah dari ratu atau agar dapat bekerja untuk ratu. Na'ùżu bi Allah min 'ilmi lā yanfa'u).

Dari pernyataan di atas, jelas bahwa fashion menjadi identitas pembeda ulama dalam komunitas santri dengan ulama keliling serta ulama yang berafiliasi dengan pemerintah. Menurutnya, ulama harus dependen dalam bidang profan dan tidak menggantungkan hidupnya kepada orang lain, baik kepada masyarakat maupun kepada pemerintah. Sebagai pemimpin, ulama harus mampu memberikan contoh kepada masyarakat, terutama pengikutnya. Modal finansial adalah komponen penting yang wajib dimiliki seorang ulama.

Penting dicatat, upaya Kiai Shalih membuat diferensiasi tersebut secara bersamaan juga terlihat adanya fungsi lain dari status fashion. Fashion menjadi simbol dari ekspresi kritik Kiai Shalih kepada beberapa ulama masa itu yang menggantungkan hidupnya kepada orang lain. Dengan demikian, dapat dipahami bahwa fashion bukan hanya sebagai simbol pembeda, melainkan juga sebagai simbol bahwa ulama adalah role model atau panutan yang tepat, dan simbol dari ekspresi kritik Kiai Shalih kepada ulama lain.

\section{FASHION SEBAGAI BASIS}

\section{KARISMA}

Karisma memiliki struktur relatif yang memiliki keterkaitan erat dengan konstruksi nalar dan keadaan yang dialami masyarakat. Dalam arti, satu tempat dengan tempat lain memiliki konstruksi yang berbeda terkait adanya karisma seorang pemimpin. Zamakhsyari Dhofier (1980: 78) dalam disertasinya memberikan gambaran bagaimana karisma seorang kiai atau ulama di Jawa diperoleh. Menurutnya, sumber dari karisma kiai di Jawa bersumber dari pengetahuannya tentang Islam, pengalaman Makkah, dedikasinya mendidik santri, kepatuhannya terhadap perintah Tuhan dan kehidupannya yang terpelajar dan saleh. Hampir sama dengan Zamakhsyari, kajian Abdillah (2015) di Kalimantan justru menunjukkan bahwa sumber karisma ulama berasal dari genealogi (keturunan), pendidikan (ilmu keislaman yang dimiliki) dan kualitas kepribadian yang kuat.

Lain halnya dengan Kiai Shalih, pandangannya sama sekali berbeda dengan pemahaman tentang karisma yang selama ini kita pahami. Menurutnya, karisma justru berasal dari fashion yang merupakan perwujudan dari ekspresi sumber kekayaan seorang ulama. Kiai Shalih mengatakan, 
"Semono ugo ulama iyo ojo kasi ketingal ino ingdalem peningale awam moko dadi ora due haibah moko dadi ora rinungu dawuhe." (as-Samārān̄̄, 1317: 82) (Artinya: jangan sampai terlihat rendah derajatnya di mata publik sehingga tidak punya wibawa atau karisma dan tidak di dengar pendapatnya).

Kemiskinan yang dialami oleh masyarakat seperti diuraikan banyak pada bagian sebelumnya, menurutnya berdampak pada cara pandang masyarakat bahwa yang disebut mulia adalah kaya. "Kerono ghalibe wong zaman akhir iku ora weruh fadhilahe ilmu lan ora weruh fadhilahe mukmin namung weruhe ingkang nama mulyo iku wong sugeh" (asSamārān̄̄, 1317: 83) (Artinya: karena pada umumnya, orang zaman akhir tidak tahu tentang keutamaan ilmu dan keutamaan orang beriman, namun yang diketahui adalah bahwa yang disebut mulia adalah orang kaya).

Bahkan, dengan sangat berani Kiai Shalih berkesimpulan bahwa "Kerono ora sempurna imanul 'awam lan islame 'awam anging kelawan mal”.(as-Samārān̄̄, t.t.: 317) (Artinya; karena tidak sempurna keimanan dan keislaman orang awam kecuali dengan harta). Konklusi ini secara implisit mengandung gambaran tentang sosok Kiai Shalih sebagai aktor yang sangat sadar dan responsif terhadap situasi sosial di sekitarnya. Kendatipun hal ini pada gilirannya juga berpengaruh terhadap cara pandangnya mengenai karisma. Baginya, karisma memiliki relasi kuat dengan cara ulama dalam menampilkan dirinya di ruang publik, salah satunya melalui fashion yang menjadi ekspresi atau perwujudan dari kekayaan dan kesuksesan ulama. Dengan kata lain, karisma ulama dapat tumbuh subur bersamaan dengan kuantitas harta benda yang kemudian di ekspresikan melalui banyak cara, seperti cara berpakaian.

\section{KARISMA DAN SUARA ULAMA}

Sebelumnya, telah dijelaskan bagaimana fashion sebagai simbol dari salah satu tanda kesuksesan dan kekayaan ulama ternyata menjadi sumber dari munculnya sebuah karisma. Modal ini selanjutnya menjadi penentu atau mempengaruhi pada efektif dan tidaknya fatwa atau suara ulama di masyarakat. Kiai Shalih memandang fashion sebagai pertanda yang signifikan bagi ulama dalam berdakwah. Kiai Shalih menegaskan “...moko dadi ora due haibah moko dadi ora rinungu dawuhe." (as-Samārānī, 1317: 82) (Artinya: ..maka tidak punya wibawa atau karisma sehingga tidak di dengar suara, pendapat, atau fatwanya). “...ojo kasi ketingalan ingdalem peningale Jahilin katon ino gombal moko dadi ora lulus amar ma'rufe lan ora tumindak ilmune" (as-Samārān̄̄, 1317: 82) (Artinya: ...jangan 
sampai terlihat hina, atau [memakai pakaian] gombal [kusut atau sobek-sobek] di mata orang bodoh, karena bisa berakibat pada gagalnya amar makruf dan tidak terealisasi ilmunya).

Memang, pandangan Kiai Shalih perlu dilakukan konfirmasi lebih dalam terkait hubungan karisma dan fatwa atau suara ulama. Namun, hipotesa itu cukup beralasan ketika melihat kembali begitu intensifnya dialog Kiai Shalih dengan kondisi sosial sekitarnya. Meskipun hal ini masih menjadi hipotesis, pandangan Nico nampaknya bisa dijadikan sebagai penguat dan penegas bahwa karisma memiliki relasi kuat dengan keefektifan fatwa atau suara ulama. Nico Kaptein (2004: 127) mengatakan "the charisma of a particular individual may also play a role in the acceptance of the fatwa".

\section{GAYA DAKWAH KIAI SHALIH: SEBUAH REFLEKSI}

Gaya dakwah Kiai Shalih, sejauh penelusuran penulis, belum banyak dirumuskan oleh para peneliti dalam studinya. Rosyid (2008: 123-131) hanya menggambarkan dakwah Kiai Shalih seperti kiai pada umumnya, yakni melalui pesantren dan karya tulis, dan tidak melakukan pembacaan gaya dakwah sosial Kiai Shalih secara lebih dalam. Padahal, ini penting untuk pengembangan konsep dakwah di Indonesia mengingat kontribusinya terhadap perkembangan Islam, Jawa khususnya, sangat besar sekali. Berangkat dari studi Basri (2008) yang mengategorikan Kiai Shalih sebagai tokoh reformis realis, Burhanudin (2007: 123-130) yang memandang Kiai Shalih sebagai aktor dalam pembentukan komunitas santri, Umam (2011: 264) yang memandang Kiai Shalih sebagai aktor atas keberhasilan pembumian Islam ortodoks, bagian ini berusaha membaca gerakan dakwah Kiai Shalih yang memiliki karakteristik dan ciri khusus sebagai akibat dari komunikasi intensif dengan realitas sekitarnya. Bertitik tolak dari tiga poin gagasannya; fashion, karisma dan suara ulama sebagaimana sudah dibahas sebelumnya, strategi, metode serta gaya dakwah sosialnya diharapkan dapat terbaca dengan baik, meski tidak secara utuh.

Fase terakhir ini, berupa merefleksikan secara integral gerakan dakwah Kiai Shalih dari keseluruhan bab yang dijelaskan di atas. Komunikasinya dengan objek dakwah terbilang cukup menarik terlihat dari munculnya rumusan fashion yang digagasnya. Sebagai reformis realis, memang gerakan dakwahnya yang sangat fenomenal adalah ketika dia mampu memosisikan bahasa Jawa sebagai antitesis atas kemapanan bahasa Arab dalam Islam di Jawa. Namun, proses komunikasi yang intensif dengan objek dakwah nyatanya membutuhkan komponen lain sebagai 
penyokong kesuksesan kegiatan dakwah. Gerakan pembaruannya melalui legitimasi Aksara Pegon baginya tidak cukup dalam ruang sosial yang memiliki persoalan kompleks di dalamnya. Dia berupaya mencari alternatif lain untuk menyesuaikan kebutuhan masyarakat sehingga materi dakwah dapat diterima dengan mudah.

Secara teori, proses ini disebut sebagai self-indication, yang mana individu mengetahui akibat kontak sosial, memberi makna, kemudian bertindak berdasarkan makna yang diperoleh (Sobur, 2004: 199). Produksi simbol yang digagas Kiai Shalih merupakan konsekuensi dari makna yang diperolehnya dari komunikasi intensif dengan realitas sosial. Simbol dianggapnya sebagai komponen fundamental dalam mekanisme dakwah. Melalui simbol, Kiai Shalih berupaya melakukan intensifikasi keakraban dalam relasi ulama dengan masyarakat. Imbasnya, ulama harus mampu menjadi pusat referensi utama yang kuat di masyarakat sebagai hasil dari kemampuan mengakomodasi segala cita dan harapan yang ada dalam struktur nalar dan kebutuhan masyarakat.

Gagasan simbolnya tidak muncul atas ruang hampa. Pertimbangan sosial, ekonomi, psikologi, dan agama adalah beberapa perangkat sistem yang menjadi fondasi kokoh munculnya simbol fashion. Fashion dianggapnya sebagai media yang relevan dalam merespons struktur nalar dan kebutuhan masyarakat. Seorang pemimpin, terutama agama, harus selalu responsif terhadap kondisi demikian. Hal ini secara tidak langsung mengandung arti bahwa pemimpin ada bukan untuk dirinya sendiri dalam artian hidup sesuai dengan apa yang dianggapnya benar dan ideal, melainkan keberadaannya harus selalu mampu menciptakan strategi dan cara baru dalam mencapai tujuan yang ideal. Sikap responsif dalam hal ini dituntut sedemikian rupa untuk diadakan dalam konstruksi nalar setiap pemimpin.

Karenanya, dapat dipahami ketika Kiai Shalih mengaitkan fashion dengan karisma ulama yang pada akhirnya menentukan keefektifan fatwa, suara, diseminasi gagasan, atau produksi lainnya dari ulama. Fashion menjadi pertanda akan adanya keharusan sikap responsif ulama terhadap kebutuhan masyarakat dalam mekanisme dakwah. Sikap responsif ini tentu bisa terwujud melalui bentuk yang bervariasi tidak hanya berupa rumusan fashion, tetapi simbol-simbol lain yang merepresentasikan sikap responsif tersebut. Namun, yang jelas, dengan adanya sikap responsif ini, ulama mampu membangun karismanya dalam sebuah persepsi masyarakat sehingga hal ini menjadi modal kuat ulama dalam berdakwah. 
Dengan demikian, dapat dipahami bahwa gaya dakwah Kiai Shalih tidak hanya menekankan pada strategi atau cara mentransmisikan keilmuan semata melalui penyesuaian bahasa, misalnya. Proses intensifikasi keakraban hubungan ulama dengan masyarakat baginya sangat penting dilakukan. Karena hal ini berimplikasi pada mudahnya penerimaan dan pengakuan masyarakat terhadap segala sesuatu yang diproduksi oleh ulama. Dalam hal ini, sikap responsif terhadap konstruksi nalar dan kebutuhan masyarakat yang menjadi arena dakwahnya sangat dibutuhkan, bahkan mungkin menjadi kewajiban ulama, dalam menciptakan hubungan tersebut. Tanpa sikap responsif ini, sulit untuk bisa dikatakan ulama mampu membangun komunikasi intensif yang akrab dengan masyarakat.

Gaya dakwah Kiai Shalih bisa dikatakan sebagai upaya Kiai Shalih menampilkan wajah Islam yang responsif dan mampu menjadi sumber solusi dari segala persoalan hidup. Dia berusaha mensinergikan antara dunia religius dengan dunia profan yang ditampilkansalah satunya- melalui fashion. Sinergitas dari kedua ini dianggap sebagai basis dan rujukan spirit beragama umat yang relevan dan kompatibel dengan segala aspek kehidupan pada masa itu, terutama ekonomi

\section{PENUTUP}

Kiai Shalih Darat merupakan tokoh pembaru dakwah Islam, Jawa khususnya, pada Akhir Abad 19. Sebagai tokoh reformis realis, dia sukses membumikan ajaran Islam ortodoks di Jawa sekaligus sebagai kreator pembentukan komunitas santri. Pencapaiannya ini tidak bisa lepas dari gerakan pembaruannya dalam merekonstruksi cara berdakwah Islam pada masa itu, khususnya dalam mentransmisikan keilmuan Islam. Bahasa Jawa diposisikan sebagai antitesis atas kemapanan bahasa Arab dalam transmisi keilmuan Islam. Gerakannya ini didasarkan atas pertimbangan yang cukup matang, baik secara normatif, historis maupun sosial dan politik. Legitimasi bahasa Jawa selanjutnya direalisasikan melalui Aksara Pegon, sebuah teks berbahasa Jawa beraksara Arab.

Namun, proses komunikasi yang intensif dengan realitas sosial nyatanya membutuhkan komponen lain sebagai penyokong kesuksesan kegiatan dakwah. Gerakan pembaruannya tidak cukup dalam ruang sosial yang memiliki persoalan kompleks di dalamnya. Simbol menjadi alternatif lain yang penting suntuk menyesuaikan kebutuhan masyarakat sehingga materi dakwah dapat diterima dengan mudah.

Kiai Shalih berusaha memopulerkan Islam melalui simbol fashion sebagai 
medianya. Fashion yang menjadi wujud ekspresi kesuksesan atau kekayaan seorang ulama dan cermin dari independensi ulama dalam kehidupan profan, kemudian dijadikan sebagai simbol pembeda, role model sekaligus ekspresi kritik. Fashion, menurutnya, menjadi basis dari munculnya karisma seorang ulama dalam ruang sosial yang penuh dengan persoalan kompleks di dalamnya, terutama problem ekonomi. Karisma merupakan komponen penting dalam diri ulama, dia memiliki andil besar terhadap keefektifan fatwa atau suara ulama yang diproduksi dan disebarkan di masyarakat.

Fashion, karisma dan suara ulama memberikan petunjuk besar dalam rangka memahami gaya dakwah Kiai Shalih. Dari seluruh rangkaian penjelasan di atas, gaya dakwah Kiai Shalih tidak hanya menekankan pada strategi atau cara dalam mentransmisikan keilmuan Islam, proses intensifikasi keakraban dalam relasi pemimpin dengan masyarakat menjadi ciri khasnya dalam berdakwah. Proses ini dicapainya melalui pengadaan sikap responsif terhadap struktur nalar dan kebutuhan masyarakat. Gaya dakwahnya bisa dikatakan sebagai upaya menampilkan wajah Islam yang responsif terhadap keadaan sosial di sekitarnya.

\section{Daftar Pustaka}

Abdillah, Zulkifli. 2015. "Ulama antara Otoritas Kharismatik dan Otoritas Legal-Rasional: Studi Kasus Ustaż Haji Muhammad Zaini Djalaluddin." Al-Hikmah 8 (1):1-20.

Barnard, Malcolm. 2011. Fashion sebagai komunikasi. Yogyakarta: Jalasutra.

Basri, Basri. 2008. "Indonesian Ulama in the Haramayn and the Transmission of Reformist Islam in Indonesia (1800-1900)." Dissertation, University of Arkansas, Fayetteville.

Bruinessen, Martin van. 1998. "Biographies of Southeast Asian Ulama." Dictionnaire biographique des savants et grandes figures du monde musulman périphérique, $d u$ XIXe siècle à nos jours. Fasc 2. Paris: CNRS-EHESS.

Burhanudin, Jajat. 2004. "Islam dan Negara-Bangsa: Melacak Akar-Akar Nasionalisme Indonesia." Studia Islamika 11 (1):167-90.

—. 2007. "Islamic Knowledge, Authority and Political Power: the Ulama in Colonial Indonesia." Dissertation, Leiden: Universiteit Leiden.

Dhofier, Zamakhsyari. 1980. "The Pesantren Tradition: A Study of the Role of the Kyai in the Maintenance of the Traditional Ideology of Islam in Java." Dissertation Ph.D, Canberra: The Australian National University.

Drakeley, Steven. 2005. The history of Indonesia. ABC-CLIO.

Dzahir, Abu Malikus Salih. 2012. Sejarah dan Perjuangan Kyai Sholeh Darat Semarang. Disunting oleh M. Ichwan. Semarang: Panitia Haul Kyai Sholeh Darat Semarang.

Fikri, Ibnu. 2014. "Aksara Pegon: Studi tentang Simbol Perlawanan Islam di Jawa pada Abad XVIII-XIX." Monograph. LP2M IAIN Walisongo Semarang.

Jati, Wasisto Raharjo. 2015. "Islam Populer sebagai Pencarian Identitas 
Muslim Kelas Menengah Indonesia.” Teosofi: Jurnal Tasawuf dan Pemikiran Islam 5 (1):139-163.

Kaptein, Nico JG. 2004. "The Voice of the 'Ulamâ': Fatwas and Religious Authority in Indonesia." Archives de sciences sociales des religions, 115130.

Masrur, Mohammad. 2012. "Kyai Soleh Darat, Tafsir Fa'id Al-Rahman dan R.A. Kartini." At-Taqaddum: Jurnal Peningkatan Mutu Keilmuan dan Kependidikan Islam 4 (1):28-45.

Mas'ud, Abdurrahman. 2004. Intelektual Pesantren; Perhelatan Agama dan Tradisi. Yogyakarta: LKis.

Mas'ud, Ali. 2011. "Dinamika Sufisme Jawa: Studi tentang Pemikiran Tasawuf KH. Saleh Darat Semarang dalam Kitab Minhaj al-Atqiya'." Disertasi Program, Surabaya: Program Pascasarjana UIN Sunan Ampel.

—. 2014. "Ortodoksi Sufisme KH Shalih Darat." Islamica: Jurnal Studi Keislaman 7 (1):24-43.

Misbah, Aflahal. 2017. "Fashion dalam Konstruksi Otoritas Ulama: Pandangan Kiai Shalih Darat." Makalah dipresentasikan pada Graduate Forum Pascasarjana UIN Sunan Kalijaga, Convention Hall Lt.1 UIN Sunan Kalijaga, November 28.

Misbah, Aflahal, dan Nuskhan Abid. 2016. "Propaganda Kiai Șāliḥ Darat dalam Upaya Mewujudkan Harmoni di Nusantara (Telaah Kitab Minhāj AlAtqiyā)." FIKRAH 4 (1):96-116.

Munir, Ghazali. 2007. "Pemikiran Kalam Muhammad Salih Darat AsSamarani (1820-1903).” Disertasi Program, Yogyakarta: Program Pascasarjana UIN Sunan Kalijaga.

- 2008. Warisan intelektual Islam Jawa dalam pemikiran kalam Muhammad Shalih as-Samarani. Semarang: Walisongo Press.

Proudfoot, Ian. 1993. Early Malay printed books: A provisional account of materials published in the Singapore-Malaysia area up to 1920, noting holdings in major public collections. Academy of Malay Studies and The Library University of Malaya.

Ricklefs, Merle Calvin. 2001. A History of Modern Indonesia since c. 1200. Palgrave Macmillan.

Rosyid, Moh. 2008. "Kiai Saleh Darat: Lintasan Dakwah di Kota Semarang." Jurnal Penelitian Islam Empirik STAIN Kudus 2 (2):123-31.

Samārānī, Muḥammad Șālị̣ bin 'Umar as. 1317. Minhāj al-Atqiyā' fi Syarh Ma 'rifat al-Ażkiyā' ilā Tarīq alAwliyā'. Bombay: al-Mațba'ah alKarīmī.

. 1318. al-Mursyid al-Wajīz fi 'ilm al-Quran al-'Azizz. Bombay: alMaṭba'ah al-Karīmī.

- 1374. Majmu'at as-Syari'at alKafiyat li al-Awam. Cirebon: alMisriyyah.

- t.t. Tarjamah Sabīl al-'Abìd 'ala Jawharat al-Tawhìd.

Sobur, Alex. 2004. Semiotika Komunikasi. Bandung: PT Remaja Rosda Karya.

Soekanto, Soerjono. 2001. Sosiologi: Suatu Pengantar. Jakarta: Raja Grafindo Persada.

Steenbrink, Karel A. 1984. Beberapa Aspek tentang Islam di Indonesia Abad ke-19. Jakarta: Bulan Bintang.

Suminto, Aqib. 1985. Politik Islam Hindia Belanda. Jakarta: LP3ES.

Umam, Saiful. 2011. "Localizing Islamic orthodoxy in northern coastal Java in the late 19th and early 20th centuries: a study of pegon Islamic texts." Dissertation, [Honolulu]:University of Hawaii at Manoa.

- 2013. "God's Mercy is Not Limited to Arabic Speakers: Reading Intellectual Biography of Muhammad Salih Darat and His Pegon Islamic Texts." Studia Islamika 20 (2):243-274. 